\title{
The impact of the temperature of rapeseed oil methyl esters on nitrogen oxides emissions
}

\author{
Weronika Gracz ${ }^{1 *}$, Mirosław Czechlowski ${ }^{2}$ Damian Marcinkowski ${ }^{1}$, Wojciech Golimowski ${ }^{3}$ and Patrycja Pochwatka ${ }^{4}$ \\ ${ }^{1}$ Institute of Technology and Life Sciences; Biskupińska 67, 60-463 Poznań \\ ${ }^{2}$ Poznań University of Life Sciences, Wojska Polskiego 28, 60-637 Poznań \\ ${ }^{3}$ Wrocław University of Economics; Department of Agroengineering and Quality Analysis, \\ Komandorska 180/120, 53-345 Wrocław \\ ${ }^{4}$ University of Life Sciences in Lublin, Department of Environmental Engineering and Geodesy, Leszczyńskiego St. 7, \\ 20-069, Poland
}

\begin{abstract}
The purpose of the tests described in this publication was to examine the effect of the temperature of the biodiesel burned, resulting from the transesterification of rapeseed oil with methanol, on the level of nitrogen oxides emissions. The tests were carried out on a test stand equipped with a $9.5 \mathrm{~kW}$ engine. Electricity was transffered directly to the power grid. The measurements were started after the engine has warmed up, when the oil temperature exceeded $85^{\circ} \mathrm{C}$. In the first stage, the engine was loaded with the maximum achievable torque $(100 \%)$, in the second stage the torque was set at $75 \%$ of the maximum value, and for measurements in the third stage the torque was $50 \%$ of the maximum value. Three tests were carried out, one for each of the three fuel temperatures: 20,40 and $55^{\circ} \mathrm{C}$.
\end{abstract}

\section{Introduction}

Combustion of fossil fuels (i.e. coal, oil) causes harmful gases $\left(\mathrm{SO}_{2}, \mathrm{NO}_{\mathrm{x}}\right)$ and greenhouse $\left(\mathrm{CO}_{2}, \mathrm{CH}_{\mathrm{x}}\right)$ gases emissions to the atmosphere [1]. However, in recent years there has been an increase in the interest of politicians and scientists in issues related to climate protection and air quality [2]. Liquid biofuels of vegetable origin can be an ecological alternative to fossil fuels [3-5]. They are synthesized by transesterification of vegetable oils with methanol. Their combustion does not deepen the greenhouse effect, but is associated with higher emissions of nitrogen oxides $\left(\mathrm{NO}_{\mathrm{x}}\right)$. Due to the fact that the world is facing a growing environmental pollution, they are placed increasingly stringent emissions standards from internal combustion engines. One of the main emission of dangerous compounds in the exhaust gases are nitrogen oxides [6]. It is becoming increasingly difficult to meet the requirements of exhaust emissions standards for $\mathrm{NO}_{\mathrm{x}}$ emissions, so new methods are being sought that can effectively reduce $\mathrm{NO}_{\mathrm{x}}$ formation in combustion chambers of internal combustion engines. One method may be to regulate the temperature of fuel supplied by injection to the combustion chamber of the engine. Published research results indicate a reduction in $\mathrm{NO}_{\mathrm{x}}$ emissions by increasing the temperature of the fuel introduced into the internal combustion engine $[7,8]$, however, some reports indicate an increase in $\mathrm{NO}_{\mathrm{x}}$ emissions with increasing the temperature of the fuel burned [9]. The purpose of this study was to determine the effect of temperature changes on rapeseed oil methyl esters (RME) used as fuel for a compression ignition engine on nitrogen oxide emissions.

\section{Materials and methods}

Methyl esters from rapeseed oils were used in the studies. Rapeseed oils were transesterified at $60^{\circ} \mathrm{C}$ using homogeneous catalyst $2 \% \mathrm{~m} / \mathrm{m} \mathrm{KOH}$ and methanol in molar share 1:9. The experiment was carried out on an experimental stand consisting of: Yannmar 2TNV70ASA diesel engine, asynchronous engine, ATMX 2000 control and measurement system, exhaust fumes were tested with VARIOplus Industrial analyser. The composition of the exhaust gas was measured in the exhaust gas pipe, a straight section with a length of $1 \mathrm{~m}$ at a distance of $1 \mathrm{~m}$ from the exhaust manifold.The MRU VARIOplusIndustrial exhaust gas analyzer was used to analyze the composition of the emitted exhaust gases. The analyzer included a measuring probe designed for

\footnotetext{
Corresponding author:w.gracz@itp.edu.pl
} 
high dustiness equipped with a heated metal filter with measurement of exhaust gas temperature and heating regulation. The composition of the exhaust gas was measured using a three-electrode electrochemical sensor. The analyzer made it possible to register emission data expressed in ppm. In addition, the analyzer was equipped with a Pitot tube that allowed measuring the volume of emitted exhaust gases. Thanks to this, the analyzer system could automatically convert the emissions expressed in $\mathrm{ppm}$ to $\mathrm{mg} \cdot \mathrm{nm}^{-3}$ exhaust.

The test stand, the ATMX 2000 dynamometer, consisted of a Yanmar 2TNV70-ASA two-cylinder diesel engine with a pre-chamber, $9 \mathrm{~kW}$, liquid-cooled. It was an engine with indirect fuel injection system and sectional injection pump. The engine was permanently connected via a shaft to an asynchronous motor, controlled by an automatic control and measuring system. The OMT1-160M2 asynchronous motor was a three-phase low-voltage induction motor with a squirrelcage rotor, air-cooled. The stands were equipped with a $15 \mathrm{~kW}$ inverter MFC 710. Electricity was directed directly to the power grid

The research concerned the measurement of nitrogen oxides $\left(\mathrm{NO}_{\mathrm{x}}\right)$ emission of an RME diesel engine. The tests were carried out in accordance with ISO 8178-4 test D1 (test for engines operating at constant load). The measurements were started after the engine has warmed up, when the oil temperature exceeded $85^{\circ} \mathrm{C}$. During the measurements, the engine worked at $3000 \mathrm{rpm}^{-1} \pm 10$ $\mathrm{rpm}^{-1}$ (speed corresponding to the nominal speed of the asynchronous engine), which was set by means of the injection pump regulator. The test consisted of three stages. In the first stage, the engine was loaded with the maximum possible torque $(100 \%)$. In the second stage, the torque was set at $75 \%$ of the maximum value, while during the measurements for the third stage, the torque will be $50 \%$ of the maximum value.

During each load change, it was necessary to correct the engine speed so as to obtain the assumed value of 3000 $\mathrm{rpm}^{-1} \pm 10 \mathrm{rpm}^{-1}$. Each stage lasted 10 minutes, the first 7 minutes served to stabilize engine operating parameters, measurements were recorded for the next 3 minutes. Three tests were carried out, one for each of the three fuel temperatures: 20,40 and $55^{\circ} \mathrm{C}$.

To calculate the specific emissions from the test phase, the resulting $\mathrm{NO}_{\mathrm{x}}$ concetration $\left[\mathrm{mg} \cdot \mathrm{nm}^{-3}\right]$ was converted into the specific $\mathrm{NO}_{\mathrm{x}}$ emission expressed in $\mathrm{g} \cdot \mathrm{kWh}^{-1}(\mathrm{~A})$.

$$
E=\frac{N O_{x}\left[m g * n m^{3}\right] \cdot V\left[\frac{n m^{3}}{h}\right]}{P[k W h] \cdot 1000}\left[\frac{g}{k W h}\right]
$$

The engine load was calculated from the energy generated by the generators to the network. The power obtained was not the engine power but the power of the power generator, which includes transmission losses and gears.Conversion of the unit of nitrogen oxides content in exhaust gases. The measuring system recorded the emission of nitrogen oxides in $\mathrm{mg} \cdot \mathrm{nm}^{-3}$ exhaust gas.
Then, the $\mathrm{NO}_{\mathrm{X}}$ emission concentration was converted to $\mathrm{g} \cdot \mathrm{kWh}^{-1}$ according to the equation (B):

$N O_{X}\left[\frac{g}{k W h}\right]=\frac{N O_{X}\left[\frac{m g}{n m^{3}}\right] \times V\left[\frac{n^{3}}{h}\right]}{N e\lceil k W\rceil \times 1000}$

- $\mathrm{NO}_{\mathrm{X}}\left[\mathrm{mg} \cdot \mathrm{nm}^{-3}\right]$ - content of nitrogen oxides in exhaust gases;

- V $\left[\mathrm{nm}^{3} \cdot \mathrm{h}^{-1}\right]$ - the amount of exhaust gas emitted by the engine;

- Ne [kW] - effective engine power.

\section{Results}

Table 1. Concentration NOx $\left[\mathrm{g} \cdot \mathrm{kWh}^{-1}\right]$

\begin{tabular}{|c|c|c|c|}
\hline \multirow{2}{*}{ Temperature $\left[{ }^{\circ} \mathbf{C}\right]$} & \multicolumn{3}{|c|}{ Engine load [\%] } \\
\cline { 2 - 4 } & $\mathbf{5 0}$ & $\mathbf{7 5}$ & $\mathbf{1 0 0}$ \\
\hline $\mathbf{2 0}$ & 13,58 & 9,42 & 6,75 \\
\hline $\mathbf{5 0}$ & 13,19 & 9,36 & 7,05 \\
\hline $\mathbf{7 0}$ & 12,87 & 9,23 & 7,46 \\
\hline
\end{tabular}

The emission of nitrogen oxides depends on the engine load and the temperature of the fuel introduced into the diesel engine. In the tests performed, engine load had the greatest impact on the change in $\mathrm{NO}_{\mathrm{X}}$ emissions. Along with the increase in engine load, $\mathrm{NO}_{\mathrm{X}}$ emissions were reduced. The largest reduction of $\mathrm{NO}_{\mathrm{X}}$ emissions occurred at a fuel temperature of $20^{\circ} \mathrm{C}$ and was $50 \%$, at this fuel temperature the $\mathrm{NO}_{\mathrm{X}}$ concentration values at the lowest and highest engine loads were 13.5 and 6.75 $\left[\mathrm{g} \cdot \mathrm{kWh}^{-1}\right]$, respectively. The increase in fuel temperature at $50 \%$ and $75 \%$ engine load reduced $\mathrm{NO}_{\mathrm{X}}$ emissions by $5 \%$ and $2 \%$, respectively, between the lowest and highest temperatures of the introduced fuel. However, in the case of the highest engine load, the increase in fuel temperature resulted in a $10 \%$ increase in $\mathrm{NO}_{\mathrm{X}}$ emissions. The highest $\mathrm{NO}_{\mathrm{X}}$ concentration (13.58 $\left.\left[\mathrm{g} \cdot \mathrm{kWh}^{-1}\right]\right)$ occurred at $50 \%$ engine load and $50^{\circ} \mathrm{C}$ temperature, while the lowest $\mathrm{NO}_{\mathrm{X}}$ emission value $(6.75$ $\left[\mathrm{g} \cdot \mathrm{kWh}^{-1}\right]$ ) was recorded during $100 \%$ engine load and fuel temperature $20^{\circ} \mathrm{C}$.

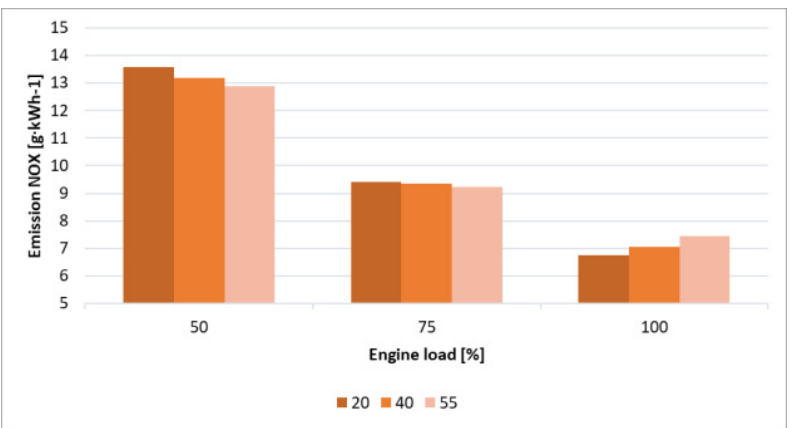

Fig. 1. Impact of fuel temperature on $\mathrm{NO}_{\mathrm{x}}$ emissions at 50,75 and $100 \%$ engine load. 


\section{Conclusion}

If the temperature of the combusted fuel increases from $20^{\circ} \mathrm{C}$ to $55^{\circ} \mathrm{C}$, there is a reduction of $\mathrm{NO}_{\mathrm{x}}$ emissions by approximately $5 \%$ for an engine running at $50 \%$ maximum load, and by approximately $2 \%$ for an engine running at $75 \%$ of maximum load, respectively.

At maximum engine load, increasing the fuel temperature increases the emission of nitrogen oxides. When increasing the fuel temperature from $20^{\circ} \mathrm{C}$ to $55^{\circ} \mathrm{C}$, an increase in $\mathrm{NO}_{\mathrm{x}}$ emissions of over $10 \%$ was observed.

Based on the D1 tests carried out according to ISO $8178-4$, it can be stated that raising the fuel temperature in the range of $20^{\circ} \mathrm{C}$ to $55^{\circ} \mathrm{C}$ slightly reduces the total emission of nitrogen oxides from a diesel engine. For the above-mentioned test fuel temperature range, the reduction of $\mathrm{NO}_{\mathrm{x}}$ emissions was less than $0.3 \%$, therefore it is not cost-effective to equip the engine with a fuel heating system operating in the tested temperature range.

\section{Acknowledgements}

Publication is funded by the Polish National Agency for Academic Exchange under the International Academic Partnerships Programme from the project „Organization of the $9^{\text {th }}$ International Scientific and Technical Conference entitled Environmental Engineering, Photogrammetry, Geoinformatics - Modern Technologies and Development Perspectives".

\section{References}

1. O. Ogunkunle and N. A. Ahmed, Energy Reports 5, 1560 (2019)

2. W. Golimowski, P. Krzaczek, D. Marcinkowski, W. Gracz, and G. Wałowski, Sustain. 11, (2019)

3. V. A. Markov, V. G. Kamaltdinov, S. A. Zykov, and A. A. Savastenko, J. Phys. Conf. Ser. 1260, 052022 (2019)

4. V. A. Markov, V. G. Kamaltdinov, A. D.

Denisov, and L. I. Bykovskaja, J. Phys. Conf.

Ser. 1260, 052021 (2019)

5. I. A. Resitoglu, A. Keskin, H. Özarslan, and H. Bulut, Int. J. Environ. Sci. Technol. 16, 6959 (2019)

6. H. Omidvarborna, A. Kumar, and D.-S. Kim, Fuel Process. Technol. 140, 113 (2015)

7. M. Senthil Kumar, A. Kerihuel, J. Bellettre, and M. Tazerout, Renew. Energy 30, 1443 (2005)

8. H. Chen, Q. Guo, X. Zhao, M. Xu, and Y. Ma, J. Energy Inst. 89, 231 (2016)

9. M. A. Kalam and H. H. Masjuki, Biomass and Bioenergy 27, 289 (2004) 